\title{
The health/disease transition process in chronic kidney disease patients: Contributions to nursing care
}

\author{
O processo de transição saúde/doença em pacientes renais \\ crônicos: contribuições para assistência de enfermagem \\ El proceso de transición salud/enfermedad en pacientes renales \\ crónicos: contribuciones para la asistencia de enfermería
}

How to cite this article:

Oliveira FA, Almeida ARLP, Mota TA, Costa JR, Andrade MS, Silva RS. The health/disease transition process in chronic kidney disease patients: contributions to nursing care. Rev Esc Enferm USP. 2020;54:e03581. doi: https://doi.org/10.1590/S1980-220X2018049203581

Francieli Aparecida de Oliveira ${ }^{1}$

Ana Raquel Lima Peralva de Almeida ${ }^{2}$

\section{Thaciane Alves Mota \\ Joice Requião Costa ${ }^{2}$ \\ Magna Santos Andrade ${ }^{2}$ \\ Rudval Souza da Silva ${ }^{1,2}$}

${ }^{1}$ Universidade Federal da Bahia, Programa de Pós-Graduação em Enfermagem e Saúde, Salvador, BA, Brazil.

${ }^{2}$ Universidade do Estado da Bahia, Campus VII, Colegiado de Enfermagem, Senhor do Bonfim, BA, Brazil.

\begin{abstract}
Objective: To identify the facilitating and hindering conditions of the health/disease transition process in a group of patients with Chronic Kidney Disease undergoing hemodialysis treatment based on the theoretical framework of the Transition Theory. Method: A descriptive study implementing a qualitative approach. Data collection occurred through semi-structured interviews conducted between March and April 2018. The Content Analysis Technique was used for analysis and discussion as a methodological framework and the explanatory model of the Transition Theory as a theoretical framework. Results: Twenty-five (25) patients participated in the study. The conditioning factors of the transition process were identified and organized into three thematic categories: Personal conditioning factors in the transition process; Community conditioning factors in the transition process; and Social conditioning factors in the transition process. Conclusion: A predominance of hindering conditioning factors was evidenced in the personal dimension, while facilitating conditioning factors were shown in relation to the community dimension, and finally the conditioning factors were equal regarding the social dimension.
\end{abstract}

\section{DESCRIPTORS}

Renal Insufficiency, Chronic; Nursing Care; Nursing Theory; Transitional Care; Renal Dialysis.
Corresponding author:

Rudval Souza da Silva

Rodovia Lomanto Júnior - BR 407, Km 127 CEP 48970-000 Senhor do Bonfim, BA, Brazil. rudvalsouza@yahoo.com.br 


\section{INTRODUCTION}

Chronic Kidney Disease (CKD) is a serious condition which affects about $12 \%$ of the global population and people of all ethnicities and age groups ${ }^{(1)}$. An individual receiving a diagnosis of CKD implies rethinking their entire lifestyle and forces them to go through a process of coping with a psychosocial disorder requiring psychological and emotional reorganization.

Hemodialysis is the most commonly implemented renal replacement therapy for treatment. This requires high dependence and demands a strict therapeutic regimen by the patient, control of water intake and restricted diet, and frequent visits to health services ${ }^{(2)}$. Thus, there is a need to adapt to continuous dialysis treatment for the rest of their life, except when kidney transplantation is possible.

Therefore, it is possible to infer that diagnosing and treating CKD lead to a process of considerable changes in the lives of people who were previously considered healthy, and from then on a condition of a patient having significant changes in their life, which can be termed as a transition process.

The Transition Theory ${ }^{(3)}$ is concerned with changes in an individual's health condition from a healthy to a sick state or from a phase of life, condition or situation to another phase which is different from the previous one; it can be a positive change or not. As a process, the transition can be described in three stages: entry (change, separation and disenchantment), passage (disorientation, disintegration and discoveries) and exit (finding new meanings, seeking control of the situation in confronting new experiences) $)^{(3-4)}$.

This theory is supported by four essential pillars, namely: the nature of the transition (type, patterns, and properties), the conditioning factors of the transition (process facilitators or difficulties related to the person, the community, and society), response patterns of the transition (process and outcome indicators, and nursing therapeutic guidelines) and therapeutic nursing interventions $s^{(3-5)}$.

Considering these pillars and observations about the daily lives of patients undergoing hemodialysis treatment, in addition to the fact that transitions are phenomena of interest to nursing, it is justified to study the transition process of these patients in order to help identify nursing care foci and thus support care planning in the field of Nephrology Nursing. It is noteworthy that the theoretical framework is a proposal which enables guiding nursing care using therapeutic interventions centered on the person in transition, although there is still a gap when it comes to studies related to people with CKD.

Given the above, it is assumed that knowing the transition conditions is a possible way to identify the attention foci for patients with CKD, so that nurses can determine the best strategy for maintaining and promoting health in patients undergoing hemodialysis treatment. To this end, the following was defined as a guiding question: what are the facilitating and hindering conditions in the health/disease transition process experienced by patients after the diagnosis of $\mathrm{CKD}$ ?
Thus, this study aims to identify the facilitating and hindering conditions of the health/disease transition process in a group of Chronic Kidney Disease patients undergoing hemodialysis treatment based on the theoretical framework of the Transition Theory.

\section{METHOD}

\section{Study DESIGN}

This is a descriptive study implementing a qualitative approach conducted in a Nephrology Clinic located in the North Piemont Region of Itapicuru, which is part of the Bahia State Network of Substitute Renal Therapy Clinics and Transplant Centers. It is a private clinic affiliated with the Brazilian Public Unified Health System which serves about 214 patients/week.

\section{Population}

Participants were selected from a convenience sample considering the immediate availability of patients to participate in the study, with the following defined as inclusion criteria: age equal to or greater than 18 years and being on hemodialysis treatment for at least six months; and exclusion criteria defined as: patients on peritoneal dialysis and those who had not started hemodialysis treatment.

\section{DATA COLleCtion}

Data collection took place between March and April 2018. The technique used was a semi-structured interview in which the script was guided by questions which addressed the health/disease transition process. The interviews lasted an average of 45 minutes each and were audio-recorded and fully transcribed. Twenty-five (25) patients were interviewed and the number of participants was defined according to the response saturation criterion ${ }^{(6)}$ established from the moment when no new elements emerged to identify the health/disease transition process conditions, so that conducting new interviews would not change the understanding of the studied phenomenon. Sequenced codes $(\mathrm{I} 1, \mathrm{I} 2, \ldots)$ were used to identify the participants in order to preserve their anonymity.

\section{DATA ANALYSIS AND PROCESSING}

The data were organized based on the Content Analysis Technique ${ }^{(7)}$ following the three recommended stages: pre-analysis, in which the participants' speech was initially read; material exploration, when it was possible to identify the units of records inherent to the health/disease transition process conditions, which were then classified and coded, and lastly grouped by the convergence into units of meanings; and finally, processing the results, in which it was possible to aggregate and prioritize the personal, community and social conditioning factors in the transition process to be interpreted and discussed according to the theoretical framework.

The analysis of the material is based on the concepts presented by Afaf Meleis'Theory of Transitions ${ }^{(3-5)}$, which discusses changes in health situation and the conditions which favor or prevent the transition considering the individual, 
community and social aspects, enabling to organize the knowledge related to events and responses experienced by the individual during the transition process.

\section{ETHICAL ASPECTS}

The study was approved by the Research Ethics Committee of the Universidade do Estado da Bahia receiving Opinion No. 2.520.451/2018, as recommended by Resolution 466/2012 of the National Health Council involving research with human beings.

\section{RESULTS}

Twenty-five (25) CKD patients participated in the study, 16 males and nine females. Their age ranged from 18 to 70 years; 15 patients reported having more than two years of diagnosis and declared themselves as having brown skin; 16 reported having incomplete elementary school, one had completed elementary school, three had completed high school, three had incomplete high school, one reported having completed higher education, and one was illiterate. In terms of income, 22 patients reported receiving Continued Benefits $(B P C)$ provided by the National Institute of Social Security (INSS), with a predominance of income of up to one minimum monthly salary.

Conditioning factors of the transition process emerged from an analysis of the interviewees' statements in the interviews, which were then categorized as: personal, community and social conditioning factors of the transition process. Moreover, a Concept Map of the conditioning factors (facilitating and hindering factors) was developed with emphasis on the three categories in order to give better visualization of the results, based on the transition process to CKD and according to the life experiences of each participant (Figure 1).

\section{Personal Conditioning factors IN the transition PROCESS}

Receiving a diagnosis of CKD causes a transition process which requires access to a framework of perceptions and personal meanings about oneself and the disease, which tends to trigger multiple feelings and attitudes based on the person's ability to perceive themselves in relation to the CKD diagnosis.

In this sense, the feelings associated with the conditions which hinder the transition predominated, with expressions showing fear, unhappiness, desolation, denial of the disease and a desire for death. However, feelings associated with facilitating conditions were also observed, namely: resignation, acceptance and resilience.

There was a time I tried to kill myself and my family wouldn't let me. To this day I feel like it, I don't feel like doing the treatment, no. If God would take me soon (...) It would be good (I1).

At the moment I felt very sad and depressed. I was shocked, I panicked. I became debilitated, depressed, not eating, not wanting to see people. Asking for death (I12).

It was happiness. If it was prepared by God I have to face life (I23).
There was a predominance of facilitating conditions in the attitudes shown towards the transition to living with a chronic disease ranging from coping with the disease to its acceptance. Crying was an expression of these sentiments, sometimes as a relief, sometimes as an outburst. Passivity, omission, self-abandonment and attempted suicide were attitudes identified as hindering.

I asked him [doctor] if there was any way my kidney could work again or not (...). Then I asked him to tell me the truth if I would soon be able to return to normal life (I4).

I was speechless. I just cried. The news choked me. Crying relieved me a lot (I19).

Now that I'm sick they [family] don't care about me anymore, my family has changed (I21).

Receiving the diagnosis represented impacting changes in the daily lives of each of these people, leading to negative experiences which hindered the transition process, being related to a loss of independence, impossibility to work and financial dependence.

I can't do everything, I can't gain weight, sometimes I feel bad (I5).

I always have to wait for others to be available to help me, but they are not always available to help me (I16).

I was active, worked, walked. Now I have this commitment to come bere (I18).

The lack of knowledge about the disease, the treatment, and the repercussions on life show ambiguity in the conditioning factors of the transition process, sometimes as facilitators, sometimes as hindering, despite their predominance.

I didn't know. I found out later. Knowing makes it possible to get basic care early on. It was my wife who found out a lot and printed a lot of things (I9).

I didn't know at all. (...) It was good not to know exactly what it was (I10).

I didn't know. (...) I didn't know anything. And those horrible catheters. So I knew nothing, and it was bad for me (I18).

\section{COMMUNITY CONDITIONING FACTORS IN THE TRANSITION PROCESS}

The community conditioning factors refer to family processes and daily life groups arising from triggering the transition.

Positive family relationships become resources of support, help and protection to cope with changes in the role played in the family context. The facilitating conditions identified were: feeling cared for and loved; closeness of family members and being more caring; and family support in decision-making regarding the treatment option. The hindering factors, although less frequent, were characterized by feelings of rejection and abandonment, feeling as a burden to the family and withdrawal from family and community life. That thing of looking at you as if you are a dying candidate, this rattles anyone. There are people who made jokes (I10). 
My brothers came closer to me [pause] to talk. (...) they supported and influenced me [in the choice of treatment] (I11).

Now when I'm sick they don't care about me anymore and the family has changed (I17).

Before I didn't have their attention, nobody remembered that I existed. And today, after the treatment, they value me. It's great to feel loved (I22).

The patients show that they sought strength and support from organizations at the time of diagnosis and in the course of the transition, especially those related to faith. It was observed in the speeches that the church as a religious temple represents a common collective within the community spaces and was a contribution for these patients. A condition of living in the city or a short distance from the residence in relation to the clinic were conditions which contributed to facilitate the transition.

Living outside the city where the clinic is located makes it dificult. I think the round trip is worse than being here (I11).

Sometimes when we are sad, the church always helps to increase your bravery and courage (E25).

\section{SOCIAL CONDITIONING FACTORS IN THE TRANSITION PROCESS}

Patients as social subjects are linked to structured social organizations and their experiences through the access to this collective device can influence or alter the course of transition.

CKD interferes with patients'work activities and imposes the need to reorganize their way of life supported by work, which changes their leisure and relaxation routine. The most difficult transitional conditions identified were the most prevalent, with feelings of helplessness, loss of autonomy and inability to work being expressed the most in the speeches.

I can't reconcile work and treatment (I8).

I went to parties and played football, I played and now I can't anymore (I13).

I changed a lot. When I was healthy I went to clubs, got together with friends to have a beer, and today I don't do any of that anymore (I22).

\section{CONCEPT MAP}

It was possible to develop the concept map (Figure 1) based on the participants' life experiences and considering their speeches in relation to the transition process from a healthy life to living with CKD, and thus enable better visualization of the conditioning factors, facilitators and hindering, which contributed to a healthy transition and those which led to an unhealthy transition based on personal, community and social determinants.

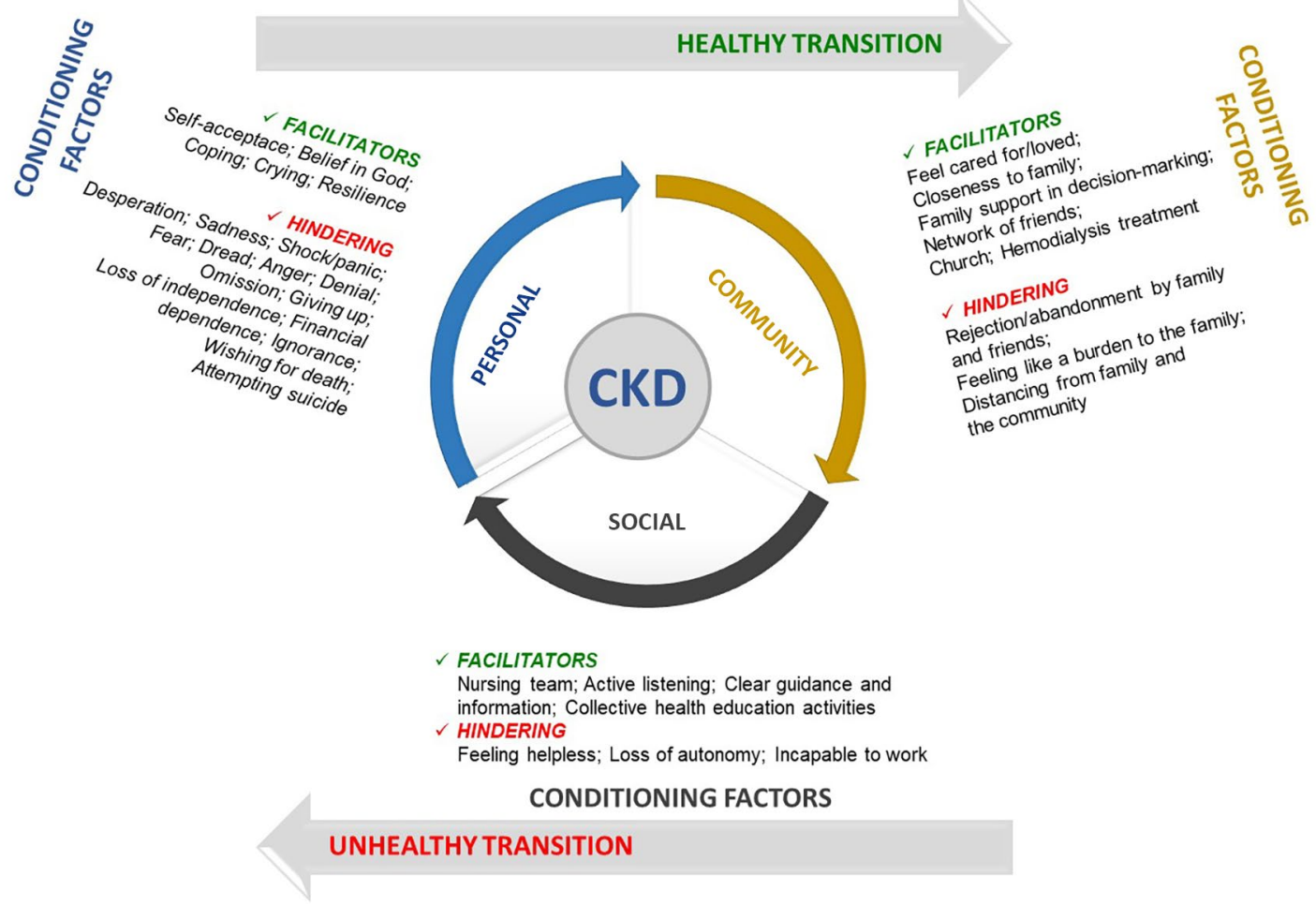

Figure 1 - Concept map about the conditioning factors for a healthy or unhealthy transition - Senhor do Bonfim, BA, 2018.

\section{DISCUSSION}

Transition, whatever its nature, has a unique course for each individual. Thus, the conditioning factors of the transition process often make the individual vulnerable and thus eventually lead them to a prolonged, painful and harmful transition process $^{(5)}$.

The personal conditioning factors in this study indicate that patients confronted the diagnosis moment as generating 
feelings which hindered the transition process. Fear of the unknown disease led patients to nervousness, sadness and despair, highlighting their vulnerabilities in confronting the uncertainties of living with CKD, showing that the emotions felt in a transition expressed fragility and insecurity when discovering the chronic disease ${ }^{(8)}$.

Denial of the disease appears in the patients' speeches, sometimes as a negative feeling, sometimes as a proactive attitude; however, both denote difficulties in the transition process. Conscious or unconscious denial indicated a person in the pre-transition phase; however, even in denying the disease, the lack of manifesting such awareness does not prevent the appearance of a transition experience ${ }^{(3,5)}$, despite the person internally recognizing that this is a painful, dependent process with no prospect of improvement.

The reports of crying generated when the news was received regarding the disease appears as an expression of fear and panic. Crying is perceived as an expression of fragility and insecurity when discovering the disease, manifesting beyond the feeling of relief, a negative burden with a sense of revolt regarding the impaired health condition ${ }^{(9)}$. However, it is ambiguously inferred from the statements of some participants that crying enables a sincere expression of intimate feelings providing relief, thus it was understood as a facilitating conditioning.

The impacts of the changes which occurred in the transition process led the participants, especially the male ones, to a desire to die and to attempt suicide, giving rise to interpretations which consider these factors as hindering this process. Studies corroborate this in pointing out that there is a significantly higher risk of committing suicide among chronic kidney disease patients compared to the general population $^{(10)}$, particularly when observing gender, as the rates of suicide attempts are higher among men ${ }^{(11)}$.

The results show the close relationship between the lack of knowledge about CKD present in the speeches of most participants, and the negative feelings and suffering experiences at the time of learning about the diagnosis. Similarly, a quantitative approach study ${ }^{(12)}$ which aimed to assess CKD patients' knowledge about their therapy showed that they had limited and restricted understanding of their disease and the forms of treatment. Thus, the results allow to infer that ignorance acts as a stressing factor, hindering the transition process, as evidenced by the results. However, ignorance also surprisingly acted as a protective factor for a minority of participants, thus facilitating the transition.

The transition process importantly causes the need for behavioral adjustments in people who experience it and is characterized by periods of intense change marked by an initial phase or entry stage (as the theory calls it) ${ }^{(3-5)}$. The participants of this study pointed out that a behavioral adjustment in seeking health goes through coping soon after diagnosis (the early phase), given the intensity of CKD symptoms manifested in the more advanced stages of the disease, being considered a conditioning factor.

Moreover, the results show that acceptance of the disease, the belief in a superior being, the belief in God, religiosity, spirituality and faith are correlated conditions and contribute to coping with the disease. These elements provide support which assists during the transition process and contributes to developing self-awareness about one's own health condition. Thus, they act as facilitators of the transition process, and significant elements in the patient's evolution process ${ }^{(13-15)}$.

The impact of CKD on a patient's life is sometimes difficult to cope with; however, a resilient attitude as a response strategy facilitates the transition, as it has the sense of returning to a point of well-being compared to the one before the diagnosis, in order to indicate a troubled period concluding and a shift to a period of greater stability which is characteristic of the healthy transition process ${ }^{(5,16)}$. This is a way to recover and reorganize as soon as possible, making their transition process less painful for them, and in some ways having less impact on family life.

Facilitating conditions predominated regarding the community conditioning factors, which contributed to overcoming the changes caused by CKD and to living with the disease.

Living daily with CKD gives patients intense losses and changes in all areas of their life. It limits the way they live due to the various physiological complications arising from the evolutionary process of the disease. This data is corroborated by other studies which point out the limitations to $\operatorname{work}^{(17)}$, financial dependence ${ }^{(17-18)}$ and impairment of their independence for daily activities ${ }^{(19)}$ as the main limitations faced by patients. They are characterized by difficult transition experiences which make life more difficult and are related to the loss of autonomy in making decisions about their own life.

The family is part of the support network accessed by patients with CKD and has a fundamental role in coping, overcoming the limitations and adaptation of these patients to the disease. In the participants' speeches, they reported bravery, the attention received and the satisfaction in feeling cared for and loved by the family. Thus, the offer of love, dedication and tranquility by family members are predictive for reducing suffering and anguish caused by CKD concerns, favoring more effective care ${ }^{(20)}$.

CKD patients have a satisfactory perception of the emotional family support received ${ }^{(13,21)}$. From the reports one can infer that the behavior of seeking family support was a facilitating condition, because it brings in the condition of offering emotional support, the comfort provided by attention, listening, esteem and companionship. Therefore, the lack of this support is closely related to an increase of suffering, because they feel helpless and abandoned, thereby negatively interfering as a hindering condition of the transition process ${ }^{(11)}$.

The family nucleus is pointed out as the main element of the social support network for patients living with CKD, and a lack of this network may increase the chances of less satisfactory outcomes for these patients and therefore of an unhealthy transition ${ }^{(22)}$.

Feeling supported in the decision on the type of treatment to follow represented an attitude of encouragement, as the statements indicate. In this sense, the family is considered an important link to overcome the difficulties when facing the disease and in adhering to treatment ${ }^{(20,23)}$.

The statements by the interviewees point to an interrelation between the dedication of family members, their 
approach to the CKD patient and the changes that occurred regarding the role that family members play in the home context. Thus, support offered by relatives generally provides the security and energy necessary to overcome the difficulties experienced ${ }^{(20)}$ in the health/disease transition process.

Nevertheless, patients, regardless of gender, expressed conflict in the role change. The diagnosis brought changes in their performed role and in the perception of helplessness in this performance characterized by behaviors and feelings associated with perceived disparity in fulfilling obligations or expectations of roles ${ }^{(5)}$.

Even regarding such a limiting disease as CKD, family and community experiences tend to generate feelings of security and emotional balance ${ }^{(16)}$, while negative experiences arising from stress overload can produce feelings of worthlessness and burden to the family ${ }^{(18-19)}$.

The results are corroborated by other studies ${ }^{(18,20)}$ in concluding that prejudice and withdrawal from friends and family are related to a lack of knowledge about the disease and renal therapy. Thus, a more painful transition process for the patient is established, while acceptance of the disease and treatment includes the support received from the particular community configured in the networks of relatives and friends.

Chronic kidney disease patients seek support in the community spaces which are part of their nearest support network in the course of the transition process. In this sense, the participants' statements indicated the network of friends as a safe contribution to the transition, as they offer emotional support and contribute to building resilience ${ }^{(14)}$ and are a determining factor for the treatment success ${ }^{(17)}$.

Coping with the disease and seeking treatment also include the religious belief of each patient, given that religious practices have strong influences on adaptive and positive responses to complex situations as a result of the disease ${ }^{(14)}$. Thus, practicing religion and spirituality are important elements for improving the quality of life of chronic renal patients, helping to cope with the disease ${ }^{(16,24)}$.

Although CKD treatment has a number of limitations and dependence on the hemodialysis machine is a stressor, and most of the time these are seen as hindering factors in the transition and adaptation process, the results show that participants perceive hemodialysis and the treatment regimen as a pursuit for improving their quality of life, and therefore these conditions have a significance of facilitating the transition process.

Furthermore, in the speeches regarding the community resources as support, it was noticed that living in the city where the treatment is performed or at short distances are conditions considered as facilitators, as they make access and continuity of treatment possible. In contrast, patients who live a long distance from the clinic reported that this is a factor which hinders treatment because they have to spend long hours and there are still climatic factors which interfere with the duration of travel. Thus, one can infer that the well-being and quality of life of the patient may be compromised, as long trips promote fatigue and make the treatment more tiring than expected.

Regarding social conditions, they were expressed in changes related to working life and leisure activities, in which patients need to dispense more energy, and they were regarded as being demanding or painful.

Abandoning work and social activities for most patients is due to the limitations caused by CKD. Patients reported feelings of helplessness and loss of autonomy due to the need to satisfy the demands imposed by the treatment, i.e. three hemodialysis sessions weekly.

These changes in lifestyle are recognized as hindering conditions of the transition process, as abandoning employment has a great impact on social and financial life, in addition to causing a reduction in pleasant activities with the family as a result of the time taken to perform the hemodialysis sessions ${ }^{(8,13)}$.

The feeling of unproductivity present in the interviewees' statements is related to the sense of inability to work due to an arteriovenous fistula, which also represents a social stigma due to the strange behavior of others in social life when they perceive the arteriovenous fistula or catheter for hemodialysis. There is also the limitation imposed by the treatment in participating in leisure activities. Similar results were found in recent studies conducted in the south of Brazil ${ }^{(25)}$.

\section{CONCLUSION}

This study enabled identifying the facilitating and hindering conditions of the health/disease transition process in patients with CKD diagnosis, and it was possible to categorize the results and the main evidence of the transitions according to the personal, community and social dimensions based on the Transition Theory. It is worth highlighting the predominance of hindering factors in the personal dimension, facilitators in relation to the community dimension, and the equal conditioning factors regarding the social dimension.

It can be concluded that the transition process experienced by CKD patients is complex and has a multiple and simultaneous pattern which provides better understanding and perception of their transition experiences. Resilience is the main facilitating condition in the personal dimension which enables emotional stabilization of the patient, promoting healthy results in the transition process. The presence of family, friends and religious belief in the community dimension are part of the support for coping and overcoming the limitations imposed by the disease. Lastly, activities related to working life and leisure activities in the social dimension were those which suffered the most negative changes.

Knowledge about these conditioning factors may help to understand how these patients perceive their transition and what prevents them from following a healthy transition, so as to support nurses in their clinical judgment when performing the nursing process, and for facilitating care planning in selecting Therapeutic Nursing Interventions.

This study is limited since it was performed in only one hemodialysis clinic with specificities regarding the profile of patients treated there, as well as the use of only one collection technique and the convenience sample, and therefore it is not generalizable to contexts which do not have similar characteristics. 


\section{RESUMO}

Objetivo: Identificar os condicionantes facilitadores e dificultadores do processo de transição saúde/doença num grupo de pacientes com Doença Renal Crônica em tratamento hemodialítico sustentado no aporte teórico da Teoria das Transições. Método: Estudo descritivo de abordagem qualitativa. A coleta de dados ocorreu por meio de entrevistas semiestruturadas realizadas no período de março e abril de 2018. Para análise e discussão, utilizou-se da Técnica de Análise de Conteúdo como referencial metodológico e o modelo explicativo da Teoria das Transições como referencial teórico. Resultados: Participaram da pesquisa 25 pacientes. Foram identificados os fatores condicionantes do processo de transição, esses foram organizados em três categorias temáticas: Condicionantes pessoais no processo de transição; Condicionantes comunitários no processo de transição; Condicionantes sociais no processo de transição. Conclusão: Foi evidenciada uma predominância de condicionantes dificultadores na dimensão pessoal, facilitadores com relação à dimensão comunitária e, no que tange à dimensão social, os condicionantes foram equânimes.

\section{DESCRITORES}

Insuficiência Renal Crônica; Cuidados de Enfermagem; Teoria de Enfermagem; Cuidado Transicional; Diálise Renal.

\section{RESUMEN}

Objetivo: Identificar los condicionantes facilitadores y dificultadores del proceso de transición salud/enfermedad en un grupo de pacientes con Enfermedad Renal Crónica en tratamiento hemodialítico sostenido en el aporte teórico de la Teoría de las Transiciones. Método: Estudio descriptivo de abordaje cualitativo. La recolección de datos ocurrió mediante entrevistas semiestructuradas realizadas en el período de marzo a abril de 2018. Para análisis y discusión, se utilizó la Técnica de Análisis de Contenido como marco de referencia metodológico y el modelo explicativo de la Teoría de las Transiciones como marco de referencia teórico. Resultados: Participaron en la investigación 25 pacientes. Fueron identificados los factores condicionantes del proceso de transición, y esos fueron organizados en tres categorías temáticas: Condicionantes personales en el proceso de transición; Condicionantes comunitarios en el proceso de transición; Condicionantes sociales en el proceso de transición. Conclusión: Fue evidenciada una predominancia de condicionantes dificultadores en la dimensión personal, facilitadores con relación a la dimensión comunitaria y, en lo que se refiere a la dimensión social, los condicionantes fueron ecuánimes.

\section{DESCRIPTORES}

Insuficiencia Renal Crónica; Atención de Enfermería; Teoria de Enfermeria; Cuidado de Transición; Diálisis Renal.

\section{REFERENCES}

1. Piccolli AP, Nascimento MM, Riella MC. Prevalence of chronic kidney disease in a in southern Brazil (Pro-Renal Study). J Bras Nefrol. 2017;39(4):384-90. DOI: http://dx.doi.org/10.5935/0101-2800.20170070

2. Frazão CMFQ, Delgado MF, Araújo MGA, Silva FBBL, Sá JD, Lira ALBC. Cuidados de enfermagem ao paciente renal crônico em hemodiálise. Rev Rene. 2014;15(4):701-9. DOI: 10.15253/2175-6783.2014000400018.

3. Meleis Al. Theoretical nursing: development and progress. 4th ed. Philadelphia: Lippincott Williams \& Wilkins; 2012.

4. Chick N, Meleis Al. Transition: a nursing concern. In: Chinn PL, editor. Nursing research methodology. Boulder: Aspen; 1986. p. $237-57$.

5. Meleis Al. Transitions Theory. Middle range and situation specific theories in nursing research and practice. New York: Springer; 2010.

6. Nascimento LCN, Souza TV, Oliveira ICS, Moraes JRMM, Aguiar RCB, Silva LF. Theoretical saturation in qualitative research: an experience report in interview with schoolchildren. Rev Bras Enferm. 2018;71(1):228-33. DOI: http://dx.doi.org/10.1590/0034-71672016-0616

7. Bardin L. Análise de conteúdo. 5ª ed. Lisboa: Edições 70; 2011.

8. Ibiapina ARS, Soares NSA, Amorim EM, Souza ATS, Sousa DM, Ribeiro IP. Aspectos psicossociais do paciente renal crônico em terapia hemodialítica. Sanare [Internet]. 2016 [citado 2018 mai. 25];15(1): 25-31. Disponível em: https://sanare.emnuvens.com.br/sanare/article/ viewFile/924/553.

9. Viegas AC, Muniz RM, Schwartz E, Machado FA, Barboza MCN, Monfrim XM. Young adults undergoing hemodialysis: from the discovery of the disease todifficulties faced in diagnosis and treatment. Rev Enferm UFPE on line. 2017;11(6):2339-48. DOI: 10.5205/reuol.1082796111-1-ED.1106201712

10. Andrade SV, Sesso R, Diniz DHMP. Hopelessness, suicide ideation, and depression in chronic kidney disease patients on hemodialysis or transplant recipientes. J Bras Nefrol. 2015;37(1):55-63. DOI: http://dx.doi.org/10.5935/0101-2800.20150009

11. Nepomuceno FCL, Melo Jr IM, Silva EA, Lucena KDT. Religiosity and quality life of chronic renal failure patients under hemodialysis treatment. Saúde Debate. 2014;38(100):119-28. DOI: http://dx.doi.org/10.5935/0103-104.20140006

12. Santos RLG, Oliveira DRF de, Nunes MGS, Barbosa RMP, Gouveia VA. Evaluation of the knowledge of chronic renal patients in conservative treatment about dialytic modalities. Rev Enferm UFPE on line. 2015;9(2):651-60. DOI: 10.5205/reuol.7028-60723-1-SM.0902201522

13. Hassani P, Otaghi M, Zagheri Tafreshi M, Nikbakht-Nasrabadi A. The process of transition to hemodialysis: a grounded theory research. Iran J Nurs Midwifery Res. 2017;22(4):319-26. DOI: 10.4103/ijnmr.IJNMR_229_15

14. Moreira JM, Matta SM, Kummer AMe, Barbosa IG, Teixeira AL, Silva ACS. Neuropsychiatric disorders and renal diseases: an update. Braz J Nephrol. 2014;36(3):396-400. DOI: http://dx.doi.org/10.5935/0101-2800.20140056

15. Silva RAR, Souza VL, Oliveira GJN, Silva BCO, Rocha CCT, Holanda JRR. Coping strategies used by chronic renal failure patients on hemodialysis. Esc Anna Nery. 2016;20(1):147-54. DOI: 10.5935/1414-8145.20160020

16. Soares MM, Calcagno GG, Madalosso VP, Heck RM, Lima EJB, Gomes VLO. Facilitators of the transition process for the self-care of the person with stoma: subsidies for Nursing. Rev Esc Enferm USP. 2015;49(1):82-8. DOI: http://dx.doi.org/10.1590/S0080-623420150000100011

17. Cavalcante MCV, Lamy ZC, Santos EC, Costa JM. Chronic kidney disease patients in the productive phase: perception of limitations resulting from illness. Rev Med Minas Gerais. 2015;25(4):484-92. DOI: http://www.dx.doi.org/10.5935/2238-3182.20150112 
18. Rudnicki T. Chronic renal patient: Experience of hemodialysis treatment. Contextos Clínicos. 2014;7(1):105-16. DOI: 10.4013/ ctc.2014.71.10

19. Souza Júnior EA, Trombini DSV, Mendonça ARA, Atzingen ACV. Religion in the treatment of chronic kidney disease: a comparison between doctors and patients. Rev Bioét. 2015;23(3):615-22. DOI: http://dx.doi.org/10.1590/1983-80422015233098

20. Marques FRB, Botelho MR, Marcon SS, Pupulim JSL. Coping strategies used by family members of individuals receiving hemodialysis. Texto Contexto Enferm. 2014; 23(4):915-24. DOI: http://dx.doi.org/10.1590/0104-07072014002220011

21. Silva SM, Braido NF, Ottaviani AC, Gesualdo GD, Zazzetta MS, Orlandi FS. Social support of adults and elderly with chronic kidney disease on dialysis. Rev Latino Am Enfermagem. 2016;24:e2752. DOI: http://dx.doi.org/10.1590/1518-8345.0411.2752

22. Borges DCS, Furino FO, Barbieri MC, Souza ROD, Alvarenga WA, Dupas G. The social network and support the transplanted kidney. Rev Gaúcha Enferm. 2016;37(4):e59519. DOI: http://dx.doi.org/10.1590/1983-1447.2016.04.59519

23. Oliveira VA, Schwartzb E, Soares MC, Santos BP, Garcia RP, Lisef F. Relações familiares de mulheres em hemodiálise. Rev Aten Saúde. 2016;14(47):36-42. DOI: https://doi.org/10.13037/ras.vol14n47.3283

24. Brasileiro TOZ, Prado AAO, Assis BB, Nogueira DA, Lima RS, Chaves ECL. Effects of prayer on the vital signs of patients with chronic kidney disease: randomized controlled trial. Rev Esc Enferm USP. 2017;51:e03236. DOI: https://doi.org/10.1590/s1980-220x2016024603236

25. Santos BP, Oliveira VA, Soares MC, Schwartz E. Chronic kidney disease: relation of patients with hemodialysis. ABCS Health Sci. 2017;42(1):8-14. DOI: http://dx.doi.org/10.7322/abcshs.v42i1.943

Financial support:

Fundação de Amparo à Pesquisa do Estado da Bahia. 